\title{
Five Years Performance of New Introduced Salt Tolerant Hybrid Poplar clones (Mofid and P. × albaeuphratica) In Iran (West Azar-Bayjan)
}

\author{
By A. JAfari Mofidabadi ${ }^{1), *}$, A. Ghmeri-ZareH ${ }^{2)}$ and A. SAlari ${ }^{2)}$
}

(Received $6^{\text {th }}$ June 2015)

\begin{abstract}
Summary
In order to introduce new hybrids poplar clones ("Mofide" and P. $\times$ albaeuphratica) for commercial wood production in different part of country, ecological range of productivity have to be determined. Therefore, adaptability of two hybrid clones "Mofide"and its reciprocal crosses hybrid ( $P . \times$ albaeuphratica), along with Populus alba L. as local clone (Kaboodeh) were tested in Rasol Abad Salty-soil Research station during 2004-2009. The experiment was conducted through randomized complete block design (RCBD). Twenty five individual cuttings of three clones (two hybrids and one local clone) planted in 100 square $\mathrm{m}$ as an experimental plot at spacing $(2 \times 2 \mathrm{~m}$ distance $)$ and replicated three. Analyses of collected data have been done based on quantities and qualitative characters during five years. The results indicated that there were highly significant differences between clones at the 0.01 level. Populus euphratica Oliv. $\times P$. alba L. hybrid (Mofid) showed highest diameter at breast height $(11.30 \mathrm{~cm})$, and total height $(10 \mathrm{~m})$ than the others two. Low level of breast diameter height $(4.15 \mathrm{~cm})$ and total height $(5.5 \mathrm{~m})$ were observed for Populus alba L. (Kaboodeh) clone as a local poplar clone.
\end{abstract}

Key Words: Hybrid poplar, Inter specific hybrid, Populus euphratica Oliv. $\times$ P. alba L., Populus alba L. $\times$ P. euphratica Oliv.

\section{Introduction}

Iran belongs to low forest coverage countries (LFCC). Total forest area in Iran is estimated 12.4 million hectares but only 1.2 million

1) Golestan Research Center of Agriculture and Natural Resources, P.O. Box 4915677555, Gorgan, Iran.

$\left.{ }^{2}\right)$ Reassert Institute of Forests and Rangelands P.O. Box 116-13185, Tehran, Iran.

*) Corresponding author: ALI JAFARI.

E-Mail: jafarimofidabadi@gmail.com hectares can be considered as commercial forest. In spite of such a situation, forest in Iran is being damaged by many factors (BAGHERI, 1996). Annually wood production through poplar is being estimated 1.5 million $\mathrm{m}^{3}$. The wood production of poplars is higher than wood which are produced by forest.

Poplar produce 1.5 million $\mathrm{m}^{3}$ wood while the wood which are produced by forests and other wood production sources are estimated 730.000 $\mathrm{m}^{3}$ (JALLILI, 2009). Therefore wood production through fast growing trees especially poplars, became an urgent task of our government. Among poplar species, Populus euphratica Oliv. has been showed, varying degrees of tolerance to the salinity, periodic water longing, cold and arid conditions (KALAGRY et al., 2000; WIART, 1988). Unfortunately, overuse has removed many of the stems of better form, so that natural stands now usually appear small and crooked (JAFARI MOFIDABADI et al., 1998). Numerous attempts have been done to improve such a high value species, using inter-specific hybridization between Populus euphratica Oliv. $\times P$. alba L. (JAFARI MOFIDABADI et al., 1998; JAFARI MOFIDABADI and ModIR-RAHMATI, 2000; LI et al., 1983; LI and LI, 1985). Hybridization is currently used to combine desirable traits and to achieve hybrid vigor in many crops and trees (TABAII-AGHDAII and JAFARI MofidABADI, 2000, PrYor and Willing, 1983). There has been a long interest in the hybridization of poplar largely because of the benefits derived from capturing heterosis and combining desirable traits to improve the quality and amount of wood production (JAFARI MofidABADI et al., 1998). In view of its resistance to drought and salinity, Populus euphratica Oliv. has been chosen as a parental species in poplar breeding. Incompatibility which have been observed between this species with other poplars species have been solved by In vitro 
embryo culture (Li et al., 1983). Inter-specific hybrids between Populus euphratica Oliv. and $P$. alba L. have been produced into direction in Iran (JAFARI MOFIDABADI et al., 1998; (JAFARI MOFIDABADI and MODIR-RHMATI, 2000). Introduction of new hybrid poplar is a routine work in Iran. Due to various reaction of plants in different climate conditions and its economical products, test of adaptability is an urgent task of breeder particularly for introduction of new hybrid in a given areas. Adaptability of poplar trees to different climate conditions depends on the genetic potential and its interaction with environment factors (KALAGARY, 1998; YU and PulkKin, 2003). In order to introduce new poplar hybrids (Populus euphratica Oliv. $\times$ P. alba L. and Populus alba L. $\times$ P. euphratica Oliv.) in different part of country for poplar wood production particularly in saline soil, ecological ranges for economically wood production have to be determined. Therefore test of adaptability and economically wood production of Mofid (Populus euphratica Oliv. $\times$ P. alba L.) and its reciprocal crosses $(P . \times$ albaeuphratica) were studied in Rasol-Abad Salty-soil Research station of Central Research of Agriculture and Natural Resources of West Azar-Bayjan (2004-2009).

\section{Materials and Methods}

Two hundred twenty five potted one year stem cutting of three poplars clones including two hybrid ( $P . \times$ albaeuphratica, and Mofid) and one Populus alba L. (Kaboodeh) as a local clones were planted in Salty-soil Rasol abad Research station belonging to Research Center of Agriculture and Natural Resources of West Azerbaijan province during years of 2004-2009. The experiment was conducted based on Complete Randomized Block Design (RCBD) with 3 replications. Seventy five potted stem cutting were planted in three rows with $250 \mathrm{~cm}$ rowspacing and $200 \mathrm{~cm}$ space between cuttings as an experimental unit (Table 1). All the recom- mended cultivation practices such as weeding, fertilizers and irrigation were done properly at the required time. Analysis of variance and comparison of means of collected dates were carried out for total height diameter at breast height trunk height, cold and pest resistance.

\section{Results and Discussion}

There were highly significant differences between clones for height and for diameter brest height (dbh) at $\alpha=0.01$ level (Table 2 and Fig. 1). Highest growth was observed for Mofid hybrid poplar (average 5.85 and maximum 10 m) while Kaboodeh (Populus alba L.) with average $2.95 \mathrm{~m}$ (maximum $5.5 \mathrm{~m}$ ) showed lowest level of height growth (Table 3 and Fig. 1). Highest diameter at breast height was observed for Mofid (11.30 cm) while lowest level of diameters at breast height $(4.1 \mathrm{~cm})$ occurred for Kaboodeh (Table 3).

No significant differences were observed between $P$. $\times$ albaeuphratica and Mofid (Populus euphratica Oliv. $\times P$. alba L.) hybrids clones. Mofid hybrid poplar clone with 10 meter height and 11.30 hcentimeter diameter breast height showed its superiority to the Populus alba L. clone as a local tree (Table 3).

There were significant differences between clones for survival rate at $\alpha=0.05$ level in the end of five years experiment (Table 2 and Fig. 1). Mofid hybrid poplar clone showed highest survival rate $(97.5 \%)$ while lowest level of survival (84\%) was observed for Kaboodeh local clone (Table 3 and Fig. 1). Low productivity of most native poplar clones caused decreasing poplar cultivation area. Therefore use of hybrid poplar is necessary to increase wood production in many part of the country (IRAN-MENESH, 2008). Inter and intra-specific hybridization and selection of superior hybrid progeny have been caused successfully introduction of hybrid clones in country (JAFARI MOFIDABADI et al., 1998). For introduction of a new hybrid poplar

Table 1. - Origen, name and number of clones applied in this experiment.

\begin{tabular}{|l|l|l|l|l|}
\hline Origen of clone & Name of clones & $\begin{array}{l}\text { Number of } \\
\text { trees/plot }\end{array}$ & Replication & $\begin{array}{l}\text { Total number } \\
\text { of each clone }\end{array}$ \\
\hline Populus euphratica Oliv. $\times$ P. alba L. & "Mofid" & $25^{*}$ & 3 & 75 \\
\hline Populus alba L. $\times$ P. euphratica Oliv, & P. $\times$ albaeuphratica & 25 & 3 & 75 \\
\hline Populus alba L. & Kaboodeh (local clone) & 25 & 3 & 75 \\
\hline
\end{tabular}

* 25 = Five rows with 5 tree in each row. 
Table 2. - Analysis of collected dates for adaptability of three poplars clones.

\begin{tabular}{lllll}
\hline Source of variation & Df & \multicolumn{2}{c}{ MS } \\
\cline { 3 - 5 } & & Height & Dbh & Survival rate \\
\hline Clones & 2 & $119358^{* *}$ & $48.31^{* *}$ & $1353^{*}$ \\
\hline Error & 29 & 9594 & 1.76 & 253.9 \\
\hline Total & 8 & & & \\
\hline
\end{tabular}

*** significant differences at 0.01 level.

* = significant differences at 0.05 level.

Table 3. - Mean comparison of different characters of three poplar clones.

\begin{tabular}{llllllc}
\hline Clones & \multirow{2}{*}{ No } & \multicolumn{2}{c}{ Height $(\mathrm{m})$} & \multicolumn{2}{c}{ Dbh $(\mathrm{cm})$} & Survival rate \\
\cline { 3 - 6 } & & Mcan & Maximum & Mcan & Maximum & $(\%)$ \\
\hline Mofid & 75 & $5.85 \mathrm{a}$ & 10 & $5.98 \mathrm{a}$ & 11.30 & $97.5 \mathrm{a}$ \\
$P . \times$ albaeuphratica & 75 & $5.67 \mathrm{a}$ & 9.35 & $5.75 \mathrm{a}$ & 10 & $87 \mathrm{a}$ \\
Kaboodeh & 75 & $2.95 \mathrm{~b}$ & 5.5 & $2.45 \mathrm{~b}$ & 4.15 & $84 \mathrm{~b}$ \\
\hline
\end{tabular}

The same letters indicated no significant different at $\alpha=0.01$ level.

clones, superiority of hybrid against native clones have to be proved (ASAREH, 2009). Narrow and broad senses adaptability trail of Mofid and $P . \times$ albaeuphratica as its reciprocal crosses have been conducted through country for maximum use of heterotic effect in wood production (GHEMERI-ZAREH, 2008). IRANMANESH (2006) reported heterotic effect for total height and breast height diameter of hybrid poplar clones (Mofid and P. $\times$ albaeuphratica) and their superiority to the local clone Kaboodeh (Populus alba L.). In contrast to the

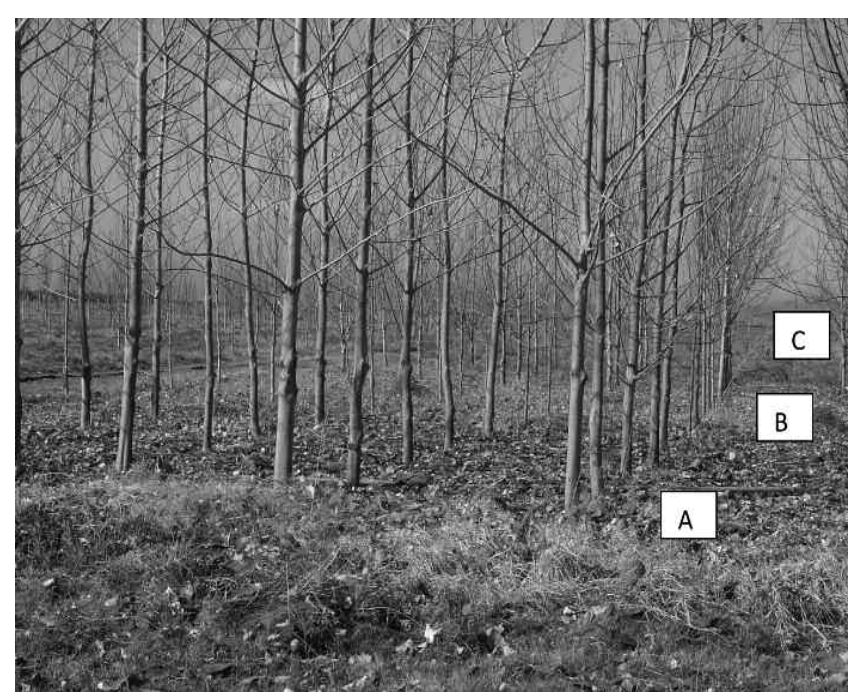

Figure 1. - A: Five year performance of Mofid, $P$. $\times$ albaeuphratica and Kaboodeh in RasolAbad salty-soil Research Station belong to Central Research of Agriculture and Natural Resources - West Azar-Bayjan Province - (A = Mofid, B = Kaboodeh, $\mathrm{C}=P . \times$ albaeuphratica $)$.
Charmehal-Bakhtiari province, which the $P . \times$ albaeuphratica hybrid clone showed superiority in trunk height and breast height diameter to Mofid hybrid clone (GHEMERI-ZAREH, 2008), higher performance was observed for Mofid in West Azar-Bayjan. In another research which was conducted by TALEBI et al. (2008), the results indicated that Kaboodeh (Populus alba L.) with high performance was the best among other different poplar clones in a five years old adaptability trail. Therefore these superior clone was used for commercial wood production in Charmehal-Bakhtiari proveince (TALEBI et $a l ., 2008)$. In a cold resistance experiment for poplars clones which were conducted by IRANMenesh (2006) in Charmehal-Bakhtiari province indicated that only Mofid hybrid clone and Populus euphratica Oliv. are sensitive to winter and spring cold condition (below minus $30^{\circ} \mathrm{C}$ ). This was due to low level cold tolerance of $P$. euphratica Oliv. as a maternal parent in Populus euphratica Oliv. $\times P$. alba L. hybrids. Terminal bud damage caused branching in upper part of Populus euphratica Oliv. $\times$ P. alba L. tree in next growing season at Chatmehale-Bkhtiyari (IRAN-MENESH, 2008), While Populus alba L. $\times$ P. euphratica Oliv. showed a high level of cold tolerance and had not been effected in minus $30^{\circ} \mathrm{C}$. This caused due to cold tolerance of Kaboodeh (Populus alba L.) as maternal parent in Populus alba L. $\times$ P. euphratica Oliv. Due to cold susceptibility of Mofid hybrid poplar clone, it was not suggested for wood cultivation program in the CharmehalBakhtiari proveince. In spite of cold susceptibil- 
ity of Mofid hybrid poplar clones, this kind of hybrid showed higher resistance than the other three against Melanophila picta Pall (TALEBI et al., 2008 and GHemeri-ZareH, 2008). This is may be due to high resistance of Populus euphratica Oliv. as a maternal parent of Mofid hybrid poplar clone (Populus euphratica Oliv. $\times$ $P$. alba L). In contrast to the CharmehalBakhtiari province which cold condition (below minus $30^{\circ} \mathrm{C}$ ) caused damage for Mofid hybrid poplar clones (IRAN-MENESH, 2006), no cold effect were observed for this clone in West AzarBayjan.

\section{Acknowledgements}

This project is supported by Research Institute of Forests and Rangelands-Thehran and Central Research of Agricultural and Natural Resources - Gorgan and all authors here express their deep appreciations.

\section{References}

AsAREH, M. H. (2009): Wood cultivation through poplars as a Table wood production approaches in Iran. Proceeding of Second National poplar Symposium in Iran. Institute of Forests and Rangelands Research. Pp. 41-51 Proceeding of Second National poplar Symposium in Iran. Institute of Forests and Rangelands Research. pp. 424-423.

BAGHERI, R. (1996): Investigation of quantitative and qualitative characters in Zanjan-Rood poplar plantation. Forest and Poplar Journal. Institute of Forests and Rangelands Research Bollten, No 7 (In Persian).

GHEMERI-ZAReH, A. (2008): Broad and Narrow sense adaptability of poplar hybrid in Iran. Final Report. Published by Institute of Forests and Rangelands Research. pp. 87.

IRAN-MANESH y. (2008): Effect of two different Populus euphratica Oliv. vegetation areas on quantitative and qualitative charecters. Proceeding of Second National poplar Symposium in Iran. Institute of Forests and Rangelands Research. pp.424423 (In Persian).
IRAN-MANESH y. (2006): Narrow sense adaptability of poplar hybrid in Charmehal-Bakhtiari provence. Final Report. Published by Institute of Forests and Rangelands Research. pp. 92.

JAFARI MofidABADI, A. and A. Modir-RAHMeti (2000): Production of Populus euphratica Olive. $\times$ P. alba L. hybrid poplars through ovary and ovule cultures. Plant Genetic Newsletter. 122: 13-15 (2000).

JAFARI Mofidabadi, A., A. ModiR-RAhmeti and A. TAVASSOLI (1998): Application of ovary and ovule culture in Populus alba L. $\times$ P. euphratica Olive. Hybridization, Silvae Genetica 47: 332-334.

JALILLI, A. (2009): Approach to Table production of Ligno-cell lease materials in Iran. Institute of Forests and Rangelands Research publish, By Institute of Forests and Rangelands Research Bullten No 38. pp. 165-638 (In Persian).

KALAGRY, M. (1998): Investigation of Populus euphratica Oliv. Population in Karoon River J. of Pejouhesh and Sazendegi 35: 20-26 (In Persian).

Kalagrry, M., K. Jevanshir, M. Zoberi and A. ModirRAHMETI (2000): Investigation of Populus euphratica Oliv. population in Karoon-River side. Poplar and Forest Journal of Iran 4 (10-17).

LI, W. and J. LI (1985): In vitro culture of hybrid ovules in Populus. Sci. Sliv. 21: 339-346.

LI, W., R. WANG and X. ZHU (1983): On the embryo development and ovule culture of interspecific hybrids between Populus simonii and P. pyramidalis Barkh. Acta Bot Sin. 25: 409-417.

PRYOR, L. D. and R. R. Willing (1983): Growing and breeding poplar in Australia. Canbera publishing and printing Co.

TABail-AghdaiI, R. and A. Jafari Mofidabadi (2000): Introduction to Forest Tree Improvement. Published by Institute of Forests and Rangelands Research. pp. 252 (In Persian).

Talebi, M., A. R. Modirir-Rehmeti, A. Hameti, H. Jahabazi-GoJani and F. HaghighiYan (2008): Adaptability experiment for introduction of new poplar clone plantation. Institute of Forests and Rangelands Research. Final Reports.

WiarT, M. (1988): Mini monograph on Populus euphratica. International Poplar Commission, $18^{\text {th }}$ session, Sep 1988, Beijing, 1-7. ShINJI, Chen BighaO, Li Hugun. 1996. Euphrates Poplar Forest, $189 p$ (1988).

YU, Q. and P. PUlkinnen (2003): Genotype-Environment interaction and stability in growth of aspen hybrid clones. Forest Ecology and Management. 173: 25-35 (2003). 